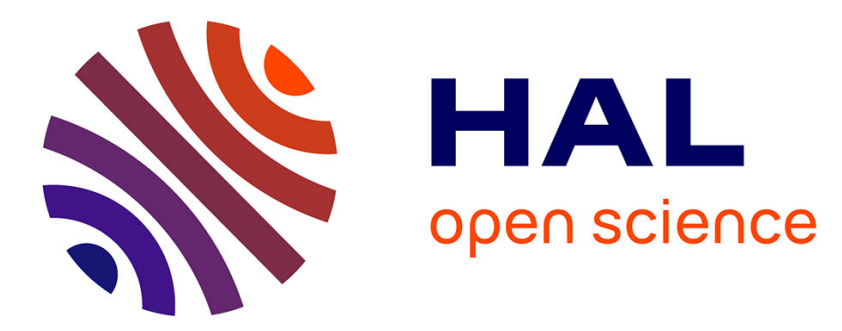

\title{
Fungal decay of viscoelastic thermal compressed (VTC) wood
}

\author{
Andreja Kutnar, Miha Humar, Frederick A. Kamke, Milan Sernek
}

\section{To cite this version:}

Andreja Kutnar, Miha Humar, Frederick A. Kamke, Milan Sernek. Fungal decay of viscoelastic thermal compressed (VTC) wood. European Journal of Wood and Wood Products, 2010, 69 (2), pp.325-328. 10.1007/s00107-010-0432-z . hal-00594486

\section{HAL Id: hal-00594486 \\ https://hal.science/hal-00594486}

Submitted on 20 May 2011

HAL is a multi-disciplinary open access archive for the deposit and dissemination of scientific research documents, whether they are published or not. The documents may come from teaching and research institutions in France or abroad, or from public or private research centers.
L'archive ouverte pluridisciplinaire HAL, est destinée au dépôt et à la diffusion de documents scientifiques de niveau recherche, publiés ou non, émanant des établissements d'enseignement et de recherche français ou étrangers, des laboratoires publics ou privés. 


\title{
EJWWP432 source
}

\section{Fungal Decay of Viscoelastic Thermal Compressed (VTC) Wood}

\author{
Andreja Kutnar ${ }^{a,}$, Miha Humar $^{\mathrm{b}}$, Frederick A. Kamke ${ }^{\mathrm{c}}$, and Milan Sernek ${ }^{\mathrm{b}}$
}

a University of Primorska, Primorska Institute for Natural Sciences and Technology, Muzejski trg 2, 6000 Koper, Slovenia; Oregon State University, Department of Wood Science and Engineering, 119 Richardson Hall, Corvallis, Oregon, USA

${ }^{\mathrm{b}}$ University of Ljubljana, Biotechnical Faculty, Department of Wood Science and

Technology, Jamnikarjeva 101, SI 1001 Ljubljana, Slovenia

${ }^{c}$ Oregon State University, Department of Wood Science and Engineering, 119

Richardson Hall, Corvallis, Oregon, USA

* Corresponding author.andreja.kutnar@upr.si, andreja.kutnar@siol.net

\begin{abstract}
Low-density hybrid poplar (Populus deltoides $\times$ Populus trichocarpa) was densified with the viscoelastic thermal compression (VTC) process to three different degrees of densification $(63 \%, 98 \%$, and $132 \%)$. Durability of the VTC treated specimens was assessed by exposure to two white rot fungi (Pleurotus ostreatus and Trametes versicolor) for four or eight weeks. After incubation, mass loss in grams and percentage mass loss were determined. The results showed that VTC densification did not change decay resistance to Pleurotus ostreatus and Trametes versicolor. The mass losses caused by Trametes versicolor were more extensive than those by Pleurotus ostreatus. As expected, longer exposure time resulted in higher mass loss. Furthermore, the degree of densification did not influence susceptibility to fungal degradation.
\end{abstract}

\section{Introduction}

Recently, a viscoelastic thermal compression (VTC) process has been developed (Kamke and Sizemore 2008). The VTC process adequately considers plasticizing of the wood and stabilization of the final product. The product, viscoelastic thermal compressed (VTC) wood, shows reduced hygroscopicity and significantly improved mechanical performance 


\section{EJWWP432 source}

(Kamke 2006). Deformations in the VTC wood are largely the result of the viscous buckling of cell walls without any fracture (Kutnar et al. 2009). The strength and stiffness of the wood material are therefore increased approximately in proportion to the increase in density (Kutnar et al. 2009). Studies of bonding properties of the VTC wood established that wood densification using the VTC process did not affect the ability of the surface of the VTC wood to properly bond with PF adhesives (Kutnar et al. 2008a, b). Therefore, the development of the VTC process has made it possible to develop new wood-based composites (Kamke and Sizemore 2008; Kutnar et al. 2008a). Since the VTC wood is intended to be used as a component in engineered composite materials, it is essential to know its durability aspects. The hydrothermal treatment in the VTC process could account for increased resistance to fungal degradation. However, it was found that thermohygro-mechanical (THM) treatment including densification did not improve the durability of Norway spruce or beech wood against Trametes versicolor and Trametes pubescence (Skyba et al. 2009). Until now, the resistance of the VTC wood to fungal degradation has not been tested. Therefore, the aim of this study was to examine the decay resistance of wood with different degrees of VTC.

\section{Materials and methods}

\section{Material preparation}

The material used in the study was low-density hybrid poplar (Populus deltoides $\times$ Populus trichocarpa) from a plantation in Northwest Oregon. The specimens were free of macroscopic defects (i.e. knots and splits). Before densification using the VTC process, all the specimens were conditioned in a controlled environment at a relative humidity of $65 \%$ and $20^{\circ} \mathrm{C}$, in order to obtain constant moisture content (MC) of $12 \%$.

The test specimens were densified using the VTC process, which consisted of three main phases (Kutnar et al. 2009). The initial phase consisted of steaming of the specimen at $860 \mathrm{kN} \mathrm{m}^{-2}$. The specimens were steamed without compression for three minute, and for an additional two minutes with a compressive force of $1380 \mathrm{kN} \mathrm{m}^{-2}$. After this treatment, the steam pressure was released, and specimen was vented for $100 \mathrm{~s}$ without compression (phase 2). During the venting period the specimen lost moisture and the temperature 
dropped. Phase 3 began with an application of a compressive loading of approximately $4480 \mathrm{kN} \mathrm{m}^{-2}$, which was applied for five minutes. However, this load was applied to mechanical stops that defined the final thickness of the specimen. Therefore, actual force on the specimen was not known. The moisture loss during venting induced the mechanosorption effect. During phase 3 the platen temperature was raised from $175^{\circ} \mathrm{C}$ to $200^{\circ} \mathrm{C}$. In the last step, the specimens were cooled under compression to $100^{\circ} \mathrm{C}$. The duration of the VTC process, including loading and unloading, was, in the case of the test specimens described in this paper, $15 \mathrm{~min}$. The specimens were compressed to a target thickness of $2.5 \mathrm{~mm}$. Since three different initial thicknesses were used $(4,5$, and $6 \mathrm{~mm})$, VTC specimens with three different degrees of densification (63\%, $98 \%$, and $132 \%)$ were created (Table 1). After the VTC process the specimens were conditioned in a controlled environment with a relative humidity of $65 \%$ at a temperature of $20^{\circ} \mathrm{C}$. At equilibrium, the VTC specimens achieved a MC of $7 \%$, which was less than the $12 \%$ of the control specimens.

Table 1 Characteristics of the VTC and control specimens (Kutnar et al. 2009)

Tabelle 1 Eigenschaften der VTC Proben und der Referenzproben (Kutnar et al. 2009)

\begin{tabular}{ccccc}
\hline & $\begin{array}{c}\text { Initial } \\
\text { thickness } \\
(\mathrm{mm})\end{array}$ & $\begin{array}{c}\text { Initial density at } \\
\mathrm{MC}=0 \% \\
\left(\mathrm{~g} \mathrm{~cm}^{-3}\right)\end{array}$ & $\begin{array}{c}\text { Density after } \\
\text { compression at } \\
\mathrm{MC}=0 \% \\
\left(\mathrm{~g} \mathrm{~cm}^{-3}\right)\end{array}$ & $\begin{array}{c}\text { Degree of } \\
\text { densification } \\
(\%)\end{array}$ \\
\hline VTC63 & 4 & 0.339 & 0.552 & 63 \\
VTC98 & 5 & 0.341 & 0.676 & 98 \\
VTC132 & 6 & 0.340 & 0.792 & 132 \\
Control & 6 & 0.331 & $\mathrm{n} / \mathrm{a}$ & 0 \\
\hline
\end{tabular}

\section{Determination of biological durability}

The resistance of the VTC wood and control wood to Pleurotus ostreatus and to Trametes versicolor was tested $(n=5)$. The initial dry mass of the specimens was determined by oven-drying the specimens at $103^{\circ} \mathrm{C}$ for 24 hours. Conditioned and steamsterilized specimens $(20 \mathrm{~mm} \times 10 \mathrm{~mm} \times 2.5 \mathrm{~mm})$ were exposed to Pleurotus ostreatus or 


\section{EJWWP432 source}

Trametes versicolor according to the mini block procedure (Bravery 1978). White rot fungi was chosen, as they predominately decay hardwood species. Specimens were exposed to fungal decay for 4 or 8 weeks for each fungus. Petri dishes with specimens were positioned in the growth chamber $\left(\mathrm{T}=25^{\circ} \mathrm{C}, \mathrm{RH}=75 \%\right)$. After respective incubation periods, specimens were oven-dried at $103^{\circ} \mathrm{C}$ to determine final dry mass. The mass loss of each specimen was determined as an absolute value in gram of the initial dry mass. The percent mass loss was then calculated for each specimen based on the initial mass; these values were then used in the calculation of mean percent mass loss for the statistical analysis.

\section{Results and discussion}

\section{Biological durability}

The VTC densification process did not change decay resistance to Pleurotus ostreatus (Table 2). After four weeks of exposure to Pleurotus ostreatus the absolute mass loss expressed in gram was the lowest in control wood specimens, while the mass loss of the VTC98 specimens was the highest (Table 2). However, the percentage mass loss shows approximately equal mass loss of different VTC wood specimens and control specimens. Longer exposure time (eight weeks) to Pleurotus ostreatus resulted in increased mass loss (Table 2) of the VTC wood and control specimens. The multiple range test with $95 \%$ LSD procedure showed that there were no statistically significant differences in the percentage mass loss of the VTC and control specimens for four and eight weeks of exposure. 
Table 2 Mass before exposure, mass after exposure, mass loss (gram and \%), and standard deviation of the VTC and control wood specimens exposed to Pleurotus ostreatus and Trametes versicolor for 4 and 8 weeks $(n=5)$

Tabelle 2 Masse vor und nach der Pilzprüfung, absoluter und relativer Masseverlust und Standardabweichung der VTC-modifizierten Proben und der Referenzproben durch Pleurotus ostreatus und Trametes versicolor nach 4 und 8 Wochen $(\mathrm{n}=5)$

\begin{tabular}{lcccc|cccc}
\hline & \multicolumn{5}{c|}{4 weeks } & \multicolumn{5}{c}{8 weeks } \\
\cline { 2 - 10 } Pleurotus & Mass & Mass & Mass & Mass & Mass & Mass & Mass & Mass \\
before test & after test & loss & loss & before test & after & loss & loss \\
& {$[\mathrm{g}]$} & {$[\mathrm{g}]$} & {$[\mathrm{g}]$} & {$[\%]$} & {$[\mathrm{g}]$} & test $[\mathrm{g}]$ & {$[\mathrm{g}]$} & {$[\%]$} \\
\hline Control & 0.2635 & 0.2449 & 0.0187 & 7.0 & 0.2572 & 0.1711 & 0.0860 & 33.7 \\
& $(0.0290)$ & $(0.0238)$ & $(0.0070)$ & $(1.91)$ & $(0.0194)$ & $(0.0230)$ & $(0.0049)$ & $(4.23)$ \\
VTC63 & 0.3407 & 0.3154 & 0.0253 & 7.4 & 0.3324 & 0.2278 & 0.1046 & 32.0 \\
& $(0.0208)$ & $(0.0184)$ & $(0.0034)$ & $(0.76)$ & $(0.0370)$ & $(0.0448)$ & $(0.0161)$ & $(7.74)$ \\
VTC98 & 0.4442 & 0.4083 & 0.0359 & 8.1 & 0.3968 & 0.2450 & 0.1518 & 38.4 \\
& $(0.0739)$ & $(0.0680)$ & $(0.0082)$ & $(1.34)$ & $(0.0255)$ & $(0.0288)$ & $(0.0131)$ & $(4.20)$ \\
VTC132 & 0.4956 & 0.4600 & 0.0356 & 7.1 & 0.5000 & 0.3492 & 0.1507 & 30.4 \\
& $(0.0290)$ & $(0.0472)$ & $(0.0085)$ & $(1.20)$ & $(0.0424)$ & $(0.0481)$ & $(0.0150)$ & $(4.37)$ \\
\hline \multirow{5}{*}{ Trametes } & Mass & 4 Weeks & & & & 8 weeks & \\
\cline { 2 - 10 } versicolor & before test & after test & loss & loss & before test & after & loss & loss \\
& {$[\mathrm{g}]$} & {$[\mathrm{g}]$} & {$[\mathrm{g}]$} & {$[\%]$} & {$[\mathrm{g}]$} & test [g] & {$[\mathrm{g}]$} & {$[\%]$} \\
\hline \multirow{2}{*}{ Control } & 0.2368 & 0.1907 & 0.0461 & 20.0 & 0.2521 & 0.1472 & 0.1048 & 41.3 \\
& $(0.0224)$ & $(0.0362)$ & $(0.0172)$ & $(8.86)$ & $(0.0293)$ & $(0.0144)$ & $(0.0238)$ & $(5.75)$ \\
VTC63 & 0.3632 & 0.3211 & 0.0421 & 11.7 & 0.3380 & 0.2266 & 0.1114 & 33.2 \\
& $(0.0445)$ & $(0.0437)$ & $(0.0086)$ & $(2.80)$ & $(0.0483)$ & $(0.0499)$ & $(0.0285)$ & $(8.71)$ \\
VTC98 & 0.4236 & 0.3675 & 0.0562 & 13.4 & 0.4120 & 0.2753 & 0.1367 & 33.3 \\
& $(0.0397)$ & $(0.0436)$ & $(0.0056)$ & $(2.28)$ & $(0.0415)$ & $(0.0333)$ & $(0.0160)$ & $(3.05)$ \\
& 0.5312 & 0.4704 & 0.0607 & 11.5 & 0.5321 & 0.3513 & 0.1808 & 34.3 \\
& $(0.0416)$ & $(0.0434)$ & $(0.0086)$ & $(1.84)$ & $(0.0439)$ & $(0.0543)$ & $(0.0187)$ & $(5.28)$ \\
\hline
\end{tabular}

The decay caused by Trametes versicolor was more extensive than the decay of Pleurotus ostreatus (Table 2). The absolute mass loss in gram after four weeks of exposure to Trametes versicolor was the lowest on the VTC63 specimens and the highest 
on the VTC132 specimens. In contrast, the percentage mass loss was the highest on the control wood specimens and the lowest on the VTC132 specimens. The multiple range test with the $95 \%$ LSD procedure showed that there were statistically significant differences in the percentage mass loss of the control wood when compared to the VTC wood specimens. However, the statistically significant differences were not found among the VTC wood specimens of different degrees of densification. Eight weeks of exposure to Trametes versicolor resulted in the higher mass loss. The absolute mass loss in gram of the VTC132 specimens was the highest and the mass loss in gram of the control specimens was the lowest, while the percentage mass loss was the highest on the control specimens (Table 2). However, the statistical analysis (multiple range test with 95\% LCD procedure) did not detect significant differences among the test specimens.

The occlusion of cell lumens in the VTC wood specimens did not inhibit decay by Pleurotus ostreatus and Trametes versicolor. This indicates that the cell wall degradation occurred by erosion troughs, the so called "type 2" degradation, which is associated with syringyl rich cell walls (Skyba et al. 2008). Furthermore, during the VTC process the cell walls of the VTC wood undergo thermal degradation of the hemicelluloses and lignin, followed by polymerization reactions of the degradation products due to heat and steam treatment (Kutnar et al. 2008c) that could alter accessibility of the VTC wood to the fungi decay. The reasons for higher absolute mass losses of the VTC wood specimens when compared to the control wood is that there was simply more wood substance present in the higher density VTC specimens, and the VTC process changed the morphology of the wood. Namely, in the VTC wood specimens the volume of the void areas decreases with the degree of densification (Kutnar et al. 2009). Therefore, in the VTC132 specimens, with the lowest void volume, the hyphae growth occurred primarily within the cell walls. In the specimens of lower degree of densification the cell lumens were open and the hyphae growth also occurred within the lumens. Additionally, the rapidly-grown plantation wood used in this study contained a large amount of tension wood. In cells of tension wood decayed by Trametes versicolor, a nonselective type of degradation may have occurred within the secondary wall and middle lamella, while the gelatinous layer was not degraded extensively due to highly crystalline cellulose (Blanchette et al. 1994). 


\section{EJWWP432 source}

The VTC process caused changes in the shape of the gelatinous layer. The gelatinous layer of the VTC wood shrank and in some cases detached from the cell wall. The deformed gelatinous layer in the VTC wood additionally promoted the hyphae growth that resulted in higher absolute mass losses of the VTC wood specimens.

\section{Conclusion}

The densification process did not significantly change the resistance of the VTC wood to degradation by Pleurotus ostreatus and Trametes versicolor. Alternatively, heat and steam treatment in the VTC process could account for the increased resistance of the VTC wood in the first four weeks of exposure to degradation by Trametes versicolor, while the degree of densification did not influence susceptibility to fungal degradation. The increased concentration of cell wall substance and occlusions of cell lumens in the VTC wood specimens resulted in higher absolute mass losses caused by Pleurotus ostreatus and Trametes versicolor decay, when compared to the control wood specimens.

\section{References}

Blanchette RA, Obst JR, Timell TE (1994) Biodegradation of compression wood and tension wood by white and brown rot fungi. Holzforschung, 48:34-42

Bravery AF (1978) A miniaturised wood-block test for rapid evaluation of wood preservative fungicides. IRG-Document IRG/WP 2113, Stockholm, Sweden

Kamke FA (2006) Densified radiata pine for structural composites. Maderas. Ciencia y technologia, 8(2):83-92

Kamke FA, Sizemore H (2008) Viscoelastic thermal compression of wood. U.S. Patent Application No. US Patent No. 7.404.422

Kutnar A, Kamke FA, Sernek M (2008a) The mechanical properties of densified VTC wood relevant for structural composites. Holz Roh- Werkst 66(6):439-446

Kutnar A, Kamke FA, Nairn JA, Sernek M (2008b) Mode II fracture behavior of bonded viscoelastic thermal compressed wood. Wood Fibre Sci 40(3):362-373 


\section{EJWWP432 source}

Kutnar A, Kamke FA, Petrič M, Sernek M (2008c) The influence of viscoelastic thermal compression on the chemistry and surface energetics of wood. Colloids Surf A: Physicochem Eng Aspects 329:82-86

Kutnar A, Kamke FA, Sernek M (2009) Density profile and morphology of viscoelastic thermal compressed wood. Wood Sci Technol 43(1):57-68

Skyba O, Niemz P, Schwarze FWMR (2008) Degradation of thermo-hygromechanically (THM)-densified wood by soft-rot fungi. Holzforschung, 62(3):277283

Skyba O, Niemz P, Schwarze FWMR (2009) Resistance of thermo-hygro-mechanically (THM)-densified wood to degradation by white rot fungi. Holzforschung, 63:639646 